\title{
NOTES TOWARDS AN ANTHROPOLOGY OF THE INTERNET
}

\author{
Keith Hart \\ Goldsmiths College, University of London - United Kingdom
}

\begin{abstract}
What might an anthropology of the internet look like? It require a combination of introspection, personal judgment and world history to explore the universe of cyberspace. This world is not sufficient to itself, nor is it 'the world'. People bring their offline circumstances to behaviour online. The virtual and the real constitute a dialectic in which neither can be reduced to the other and 'virtual reality' is their temporary synthesis. Heidegger's metaphysics are drawn on to illuminate this dialectic. Before this, the internet is examines in the light of the history of communications, from speech and writing to books and the radio. The digital revolution of our time is marked by the convergence of telephones, television and computing. It is the third stage in a machine revolution lasting just 200 years. The paper analyses the political economy of the internet in terms of the original three classes controlling respectively increase in the environment (land), money (capital) and human creativity (labour). It ends with a consideration of Kant's great example for a future anthropology capable of placing human subjectivity in world history.
\end{abstract}

Keywords: anthropology, human creativity, internet, money.

Resumo: Como poderia ser uma antropologia da Internet? Uma tal antropologia exigiria uma combinação de introspecção, de opiniões pessoais e de história mundial para se explorar o universo do ciberespaço. Afinal, esse mundo não é um mundo auto-suficiente, nem mesmo esse é "um mundo". As pessoas carregam consigo suas circunstâncias off-line para junto do seu comportamento on-line. Constitui-se uma dialética do virtual e do real, na qual nenhuma das duas partes pode ser reduzida à outra e na qual a "realidade virtual" é a sua sintese temporária. A metafísica heideggeriana é aqui acionada para esclarecer melhor essa dialética. Antes disso, entretanto, a Internet é examinada sob a luz da história das comunicações, desde a fala e a escrita de livros até o rádio. A revolução digital de nosso tempo está marcada pela convergência da telefonia, da televisão e da computação. É a terceira etapa em uma revolução das máquinas, que começou há apenas 200 anos. O presente artigo analisa a economia política da Internet em termos das três classes originais, controlando respectivamente um aumento no ambiente (terra), dinheiro (capital) e criatividade humana (força de trabalho). O artigo finaliza com uma consideração de um grande exemplo dado por Kant, de uma antropologia futura capaz de situar a subjetividade humana em uma história mundial.

Palavras-chave: antropologia, criatividade humana, dinheiro, Internet. 
Is an anthropology of the internet possible? If so, what would it look like? I will attempt a provisional answer here, building on a recent book about the consequences of the digital revolution for the forms of money and exchange (Hart, 2001). People, machines and money matter in this world, in that order. Most intellectuals know very little about any of them, being preoccupied with their own production of cultural ideas. Anthropologists have made some progress towards understanding people, but they are often in denial when it comes to the other two; and their methods for studying people have been trapped for too long in the $20^{\text {th }}$ century paradigm of fieldwork-based ethnography. I do not advocate a wholesale rejection of the ethnographic tradition, but rather would extend its premises towards a more inclusive anthropological project, better suited to studying world society, of which the internet is perhaps the most striking expression. For sure, we need to find out what real people do and think by joining them where they live. But we also need a global perspective on humanity as a whole if we wish to understand our moment in history. This will expose the limitations of the modern experiment in the social sciences - their addiction to impersonal abstractions and suppression of individual subjectivity.

Even more than before, an anthropology of the internet relies on autoethnography, on fieldwork as personal experience. We each enter it through a unique trajectory. The world constituted by this "network of networks" does not exist out there, independently of our own individual experience of it. Nor is the internet "the world", but rather an online world to which we all bring the particulars of our place in society offline. In reaching for the human meaning of the internet, we need to combine introspection and personal judgment with comparative ethnography and world history. Each of us embarks on a journey outward into the world and inward into the self. We are, as Durkheim (1965) said, at once collective and individual. Society is mysterious to us because we have lived in it and it now dwells inside us at a level that is not ordinarily visible from the perspective of everyday life. Writing is one way we try to bring the two into some mutual understanding that we can share with others. Ethnographic fieldwork, requiring us to participate in local society as we observe it, adds to our range of social experience, becomes an aspect of our socialization, brings lived society into our sources of introspection. It is feasible for some individuals to leave different social experiences in separate compartments; but one method for 
understanding world society would be to make an ongoing practice of trying to synthesize these varied experiences. If a person would have an identity, would be one thing, oneself, this entails an attempt to integrate all the fragments of social experience into a more coherent whole, a world in other words, as singular as the self (Hart, 2003).

So there are as many worlds as there are individuals and their journeys; and, even if there were only one out there, each of us changes it whenever we make a move. This model of Kantian subjectivity, at once personal and cosmopolitan, should be our starting point; but it will not do for the study of world society. Accordingly, I begin with an account of the internet seen in world-historical perspective - its origins and political economy - before turning to the dialectics of the virtual and the real that frame our personal journey through cyberspace. Here I will draw on Heidegger's metaphysics, before turning in conclusion to Kant's great example as a source for the possible renewal of the intellectual discipline he named (Kant, 1977).

\section{The origins of the internet}

Communication is a word cognate with common and community. It appears to have its root in the ability of a group or network of people to exchange things and ideas through interaction. This usually takes the form either of the circulation of material objects by means of money or the exchange of signs by means of language. The first of these is the main topic of Money in an Unequal World (Hart, 2001), but the second is a submerged current of the main argument there. The two circuits are converging in the digital revolution of our day: money is becoming information and information money. In both cases, the signs exchanged are now increasingly virtual, meaning that they take the form of bits detached from persons and places passing through the ether at the speed of light. This process of digitalization lies at the core of our moment in history; but the precedents for it go back to the origin of writing and probably further than that.

Information is an intentional signal from the perspective of the sender, perhaps anything that reduces the uncertainty of a receiver. The transmission of information through machines has traditionally come in the form of waves, imperceptible gradations of light and sound. For communications engineers, analogue and digital computation rest on 
measuring and counting, respectively: on the one hand, continuous changes in physical variables like age, height, warmth or speed; on the other, discontinuous leaps between discrete entities, such as days of the week, dollars and cents, letters of the alphabet, named individuals. Analogue processes, such as time and distance, can be represented digitally; but it was something of a breakthrough for early modern science to measure continuous physical change with precision. Before that the clarity of phenomena was generally enhanced and comparison facilitated by constructing bounded entities that could be counted, by digitalization.

Digital numeration is at its clearest when the only possible signals are binary: on/off, yes/no, either/or, 0/1. And this reversion to an older system of simple enumeration lies behind the latest revolution in communications. Digitalization greatly increases the speed and reliability of information processing and transmission; it also lies behind the rapid convergence of what were once discrete systems: television, telephones, computers. The last have been digital from the beginning, while the other two have almost completed the shift from sound waves to digital transmission. As a result, any kind of information can be carried by all types of equipment, which become essentially substitutable. Communications technology in future will consist in various combinations of screen, computer and transmitter/receiver. The manufacturing monopolists will fight over whether the resulting hybrids resemble more a television set, a $\mathrm{PC}$ or a telephone. But the process common to all is digitalization and the present moment of convergence lends our era its specificity. We should not stress information at the expense of people. For the relations we make with each other matter more than the content of the messages that pass between us or the means of their transmission. In order to place the internet within a broader context of social life, we should step back to examine its historical antecedents.

Human communication starts out as speech and the words exchanged are usually between people who can see as well as hear each other. A lot of non-verbal information accompanies the words - gestures, tone, emanations of feeling - and this helps us to interpret what is said and how to respond. This is surely why we say that social interaction is real. The words are abstract enough; but the exchange is face-to-face, grounding what passes between us in the exigency of place. Writing made it possible to detach meaning from the persons and places where it was generated and 
to communicate at some distance in time and space, not only in the here and now (Goody, 1977, 1987). Even then, the signs were often highly particular, too many for all but a select few to understand and variable from one scribe to the next. The alphabet took the process of simplifying the signs a step further, one sound for one unambiguous letter, thereby making it possible for writing to be adopted more widely and reliably. It was, if you will, a cheapening of the cost of transmitting information.

The Phoenician city states, maritime traders of the Lebanese coast, were the main pioneers of alphabetic writing at the beginning of the first millennium BC; and it came into Europe through the Greeks. I like to speculate how books were received at first. For example on Homer: "All youngsters want to do today is read at home. You can't get them to go out or anything. They have no idea what it was like hearing the old boy in a torch-lit barn on a Saturday night, with his voice echoing in the rafters. It brought tears to your eyes. Well, some of it was the smoke too." Many more people have had access to the bard over the last 3,000 years than could ever have been in the same room as him during his lifetime, even if the experience of reading is less sensational than a live performance. Virtual communication takes place more in the mind than in actual fact. The only way people could escape from the restrictions of the here and now was through exercising their imagination, usually under the stimulus of storytelling. Alphabetic writing, ultimately the book, vastly increased the scope of the collective imagination. It also made possible more practical exchanges at distance.

At more or less the same time as the alphabet (around $700 \mathrm{BC}$ ), coinage was invented in Lydia, now a part of Turkey (Keynes, 1930). Alphabetic writing and this new form of money were profoundly subversive of old ways. Until then, wealth and power were concrete and visible, being attached to the people who had them. They took the form of cattle, vineyards, buildings, armed men and beautiful women. Now riches could be concealed as gold coins, allowing for a double detachment from persons impersonal exchange at distance and unaccountable economic power (because hidden and private). From the beginning writing found a ready application in palace bureaucracy. The king could send messages while remaining himself invisible. It is one thing to be beaten up by royal thugs; but imagine the terror of receiving a written message saying "please commit 
suicide before tomorrow". We feel something of this dread whenever we receive a tax demand from the unseen hand of a remote authority.

Plato captures this in a story he tells in The Republic. Gyges was one of the Lydian king's servants. The king had a ring which made him invisible. He took Gyges with him one night to spy on his wife getting ready for bed. Gyges and the wife eventually ganged up to kill the king. Gyges got the ring, the wife and the kingdom, making him a precursor of legendary rich rulers like Midas. Marc Shell (1978) argues that this myth expresses the contradictions widely felt at the time between visible, personal society and invisible, impersonal society. The Greeks were very concerned about the security of contracts between strangers. They insisted that each contract (for which they devised the word symbolon) should be marked by an object like a ring split in the presence of both parties and a witness. They didn't quite believe in pieces of paper.

As long as books were handwritten, their circulation was restricted to a small literate elite capable of copying and reading them. In my old university, Cambridge, until the $16^{\text {th }}$ century, teachers carried their own scrolls around in the deep pockets of their gowns and read them out for payment to students who thereby ended up with their own copies. Copying was not in itself a major obstacle to the diffusion of texts. The ability to interpret the texts was scarce and costly. Printing made it possible for many more people to get hold of written material; and to an extent it eliminated some of the ambiguities of handwriting. It took a line of business away from the hacks with gowns and shifted the emphasis in learning to the act of interpretation and hence to understanding. When my students complained of a "lack of structure" in my lectures, meaning that they wanted to be told the half dozen points that, when memorized by rote, would ensure a decent pass in the examinations, I used to ask them to consider the success of Cambridge University Press over the last 450 years (McKitterick, 1992). This was built on putting books directly into the hands of students, so that they could make up their own minds what they meant, with the help of learned and hopefully inspiring teachers. Instead, today's students wanted me to revert to the role of a reader of scrolls before the print revolution, passing signs from one person to the next without touching the minds of either. 
My grandmother was born before the car, the radio, film, air travel and all the other transport and communications technologies that came to dominate $20^{\text {th }}$ century society. I used to marvel at the way she adapted to all of them. Now I am beginning to understand what she had to put up with; for, having lived through every year since the second world war, I realize how profoundly my world has changed in these respects. I grew up without television in the home and with very limited opportunities for travel; so I relied on books to get away from it all. It feels as if my intensive training in the manipulation of words and numbers (Latin, Greek and maths) now belongs to another age. I have managed to gain a toehold on the digital revolution, largely through the tolerant assistance of bright young people who have grown up with it. For them, the phase of national television that I missed is already a bygone era. We all enter this extraordinary time with a bundle of advantages and drawbacks. I take pride in a facility for writing coherent e-mail messages at a pace somewhere between a letter and a phone-call. Yet I also know that communicating through keyboards will soon be replaced by audio-visual methods, thereby removing one more link between the book and the screen. My academic colleagues are still fighting the war against television, refusing to allow one into a living room designed to show off their books. It's all relative.

One consequence of this revolution is a tendency for academics to consider books and computers to be opposed rather than complementary technologies. Yet print media are expanding almost as fast as their new electronic counterparts. Face-to-face exchanges, instead of being displaced by telecommunications, take on an added value when one spends the working day in front of a computer screen. Simple pursuits like reading and conversation, which used to be taken for granted when they monopolized our means of communication, can be approached in a more analytical and creative frame of mind now that there are so many other ways of acquiring and transmitting ideas. I do most of my writing in a Paris apartment, the long-distance writer's traditional retreat into privacy; nothing new there. But I also keep up dialogues by e-mail with friends living all over the world. And no writer was able to do that before the 1990s. I now have a virtual office to accommodate a life of movement; my laptop, but I was forced to recognize the value of my own memory when it was stolen. Each of us experiences the digital revolution in our own way; yet there are changes taking place that affect us all. 
Computers have been with us for over 50 years, television for a bit longer and telephones for twice that long. In the1990s these technologies converged with the emergence of a worldwide network of communications, the internet. The internet is the most inclusive term for all the electronic networks in the world. It is the network of networks. These are decentralized to a large extent, but they constitute a conceptual unity in much the same way as "the world market" does. Indeed the latter's transactions increasingly take place on the internet. The World Wide Web is a disembodied machine, a type of software, that emerged in 1994 for use on the internet. It allows people to display messages in a non-interactive way through a multi-media format, employing words, pictures, sound, animation and video. The big innovation at the time was the move from words and numbers to visual images. All messages are transmitted between computers and television screens (hardware) by means of telephone and radio signals. The infrastructure for these transmissions in turn constitutes a rapidly evolving network of satellites, cable grids and other means.

The internet was for several decades restricted in use to a strategic complex of military, academic and business interests, based in the United States and Europe. For some time, the most intensive use of the internet was between physicists located near the two main nuclear accelerators in Illinois and Geneva. These scientists lent to the medium its definitive style and content in the early decades: highly technical, closed and clubby. By the time that the internet went public in 1993, there were only three million users in the world. In the next five years the number of users increased to $100 \mathrm{mn}$. This figure is now estimated to be $600 \mathrm{mn}$ or 1 in 10 people alive. No previous technology has diffused so fast through the world's population. The internet is an American invention; certainly they behave as if they own it. The Europeans are now trying to get a world regulatory authority for the internet set up in Geneva. But the Americans still constitute well over half of users and most of the practical instruments for intervening in the network are located there. Several hundred satellites now make broadband communications available to users worldwide. This side of the digital revolution favours large corporations, even as it distributes the medium to an ever-widening network of decentralized users. At present, the fastestgrowing use of the internet is for electronic commerce, something almost unknown before the 1990s. At the same time, companies and private 
individuals are forming intranets, exclusive circuits of information exchange offering higher security than the public medium.

If ever there was a challenge to empiricism, the habit of extrapolating from previous experience, it is posed by trying to guess what the social impact of all this is likely to be. Compare, for example, the adoption of iron in the lands bordering the Eastern Mediterranean 3,000 years ago. Iron is the commonest metal ore on earth and it is extremely robust and malleable. When the technique of smelting it was first discovered, small quantities of iron were used principally for prestigious ornaments worn by the ruling classes. Then it found a military use as weapons which allowed some groups to gain a temporary advantage over their neighbours. It took several hundred years in most cases for iron to find its most significant application, as tools used in the production of food and manufacture by the common people. If you had happened to be living in Assyria, say, at the beginning of iron production, you would have guessed that its destiny was to be a symbolic and practical means of maintaining the dominance of a military caste. Much the same inference could have been drawn in relation to the internet at any time during the Cold War.

So what is the digital revolution? It consists of rapid changes in the size, cost and especially speed of machines capable of processing information (Naughton, 1999; US Department of Commerce, 1998). This is now measured as millions of instructions per second or MIPS. The world's first computer, the Electronic Numerical Integrator and Computer (ENIAC), was built soon after the second world war; it cost millions of dollars, was 50 metres wide and 3 metres tall, and processed 5,000 instructions per second. Twenty-five years later, an Intel micro-processor chip, $12 \mathrm{~mm}$ square, cost $\$ 200$ and processed 60,000 instructions per second (0.06 MIPS). Today Pentium 4 chips have a processing capacity of 10,000 MIPS and this is expected to reach 100,000 MIPS by 2012. In 1980 copper phone wires transmitted information at the rate of a page of print a second; today, hairthin optical fibres can transmit the equivalent of almost a million encyclopaedia volumes per second. Until recently the modems (linking computers and telephones) most commonly in use took an hour to download a five-minute video; broadband technology currently available can perform the same operation in ten seconds. 
The following table puts this contemporary cascade of technical change in context. There are three main stages of the machine revolution, marked by steam-power, electricity grids and information-processing, respectively.

Table 1. Three stages of the Machine Revolution

\begin{tabular}{c|c|c|c}
\hline & $\mathbf{c . 1 8 0 0}$ & $\mathbf{c . 1 9 0 0}$ & $\mathbf{c . 2 0 0 0}$ \\
\hline Revolution & Industrial & Bureaucratic & Digital \\
\hline Technology & Steam-power & Eletricity grids & $\begin{array}{c}\text { Information } \\
\text { processors }\end{array}$ \\
\hline Institution & Factory & Office & Internet \\
\hline Capitalism & Market & State & Virtual \\
\hline Economy & Urban & National & World \\
\hline
\end{tabular}

The steam-engine was invented in 1712; but it was another sixty years before James Watt's improvements made it feasible to power factories by this means; and the industrial revolution proper did not take off until after the Napoleonic Wars (roughly a century after Newcomen's engine). Electricity was first identified and harnessed in 1831; over fifty years later, Thomas Edison began generating it for public use. Again, only in the first decades of the $20^{\text {th }}$ century was the efficiency of factories transformed by the wholesale adoption of electric motors; and widespread domestic use of electrical appliances had to wait until the middle decades of the twentieth century. It took a hundred years from Faraday's discovery until $80 \%$ of Americans were supplied with electricity at home.

If ENIAC (its inventor being suitably anonymous for a bureaucratic age) is analogous to the inventions of Newcomen and Faraday, our time bears comparison with those moments, half a century later, when the discovery first began to have widespread social application. It seems to us that the rate of change today is much faster and more general than those earlier revolutions; and this may be a justifiable impression. Certainly, the significance of this third phase is much more far-reaching than before, if only for the internet's role in the formation of world society as a single 
interactive network. But vast populations have still barely joined the steampower or electricity grid revolutions. In parts of Africa, iron ox-ploughs in place of hand hoes are bringing agricultural production to a level of technology that has been normal in the Eurasian land mass for thousands of years. In the industrial West, human labour was replaced for most of the $19^{\text {th }}$ century not by machines, but by horses; and full mechanization of food production had to wait until the second half of the $20^{\text {th }}$ century.

It looks then as if it will be another 50 years at least before we can tell how society is being affected in the regions already open to adoption of the internet. Differences in the rate and manner of such adoption between the world's regions, classes and sectors of production will likewise only emerge in the course of the present century. Steam-power allowed factories to be located away from their principal source of energy (once water and wood, then coal) and to deploy machines replacing manual labour. These factories were operated by a new class of industrial entrepreneurs, individuals like Richard Arkwright who were later parodied in Dickens' novels (Crabtree, 1923; Dickens, 1854). Electricity helped turn factory production into a streamlined system of managerial control, powered the office complexes of the bureaucratic revolution and eventually made domestic life more convenient. It required a physical network for its distribution and this encouraged governments to own or licence monopoly operators of grids as the most tangible symbols of the national economy.

The internet harnesses light for almost instantaneous communication between machines using microscopic circuits to process and store information. There are profound implications for the system of money, for the market economy and its dark twin, capitalism. Now that the internet is no longer primarily a research tool, its use is increasingly as a sphere of economic activity, as a link between and within businesses and between businesses and their customers. It is becoming an electronic marketplace. The point about electricity is that it travels at the speed of light and the passage of information itself is essentially costless. This then is a market with unusual time and space dimensions, where the personal and impersonal aspects of economic life meet on new terms. It would not be surprising if it took us a while to adjust our expectations to this situation. In the world opening up now borderless trade is transacted at the speed of light. Very little of social significance will be left untouched before long. 


\section{The political economy of the internet}

Money markets for instruments taking countless notional forms have injected a new instability into global capitalism. The East Asian stocks bubble burst in 1998, followed not long afterwards by the dot com crash. Billions of paper assets were wiped out overnight. Mismanagement by the banks and pension funds has reached colossal proportions. This apotheosis of capital, its effective detachment from what real people do, has made many huge fortunes, often for individuals controlling billions of dollars, 220 of whom own assets equal to the annual income of just under half the world's people (United Nations Development Program, 1998). The situation is comparable to that between the first and second world wars. A stock market boom ended with the Wall Street crash of 1929. The resulting depression lasted more than a decade and provided the stimulus for building national welfare states. What political forces can regulate the present money madness in the interest of people in general? The world organization of money has now reached a social scale and technical form which make it impossible for states to control it. This may be good news for democrats and anarchists in the long run; but in the meantime state capitalism, the attempt to manage markets and accumulation through national bureaucracy, has been subverted, with rampant inequality and appalling human distress the inevitable result (Hart, 2001).

If we are to grasp the political potential of the current crisis, we should step back and revisit classical political economy, the discipline that was formed to make sense of the first machine revolution's economic consequences. Modern knowledge, as organized by the universities, falls into three broad classes: the natural sciences, the social sciences and the humanities. The academic division of labour in our day is concerned with nature, society and humanity, of which the first two are thought to be governed by objective laws, but knowledge of the last requires the exercise of subjectivity or critical judgement. Nature and humanity are represented conventionally through science and art respectively, but the best way of approaching society is moot, since social science is a recent and questionable attempt to bring the methods of the natural sciences to bear on a task that previously had fallen to religion. If science is the commitment to know the world objectively and art the means of expressing oneself subjectively, 
religion was and is a bridge between subject and object, a way of making meaningful connection between something inside oneself and the world outside. Now that science has driven religion from the government of modern societies, we must find new forms of religion capable of reconciling scientific law with personal experience.

The onset of the age of machines coincided with various attempts to develop a science of society, of which British political economy (Ricardo, 1971), French sociology (Comte, 1975) and German philosophy (Hegel, 1952) all achieved a high level of definition in the years following the end of the Napoleonic wars. Political economy was concerned with how the distribution of the value generated by an expanding market economy might best be deployed in the interest of economic growth. Smith, Ricardo and their followers identified three types of resources, each thought to be endowed with the power of increase: the environment (land), money (capital) and human creativity (labour). These in turn were represented by their respective owners: landlords, capitalists and workers. Their concern was with the distribution of specific source of income - rent, profit and wages which between them contained the key to the laws of political economy: The conflict was then between landlords and capitalists; and the policy was to ensure that the value of market sales was not diverted from the capital fund to high rents. Only later did the main issue lie between capitalists and workers.

Political economy held that competitive markets lowered the margins available to distributive agents and forced capitalists to reduce their production costs through innovations aimed at improving efficiency. This was achieved through economies of scale, division of labour and ultimately the introduction of machines to factories (Marx, 1970). The productivity of labour was thereby raised, allowing the resulting profits to be ploughed back into an expanded level of activity. Society's manpower was thereby freed up for more elaborate forms of commercial production. The only threat to this upward spiral was if landowners raised their rents to take advantage of these newly profitable industries, diverting value into wasteful consumption. Worse, whereas the capital fund was inherently limitless, land was definitely in limited supply. Economic expansion meant population growth, thereby driving up food prices and squeezing the capital fund on the other side through wages. The solution was to expose Britain's landowners to competition with cheap overseas suppliers; and this made free trade the great political issue of the mid- $19^{\text {th }}$ century. 
The basic division between classes possessing the environment, money and human creativity persists today. Indeed, writers as diverse as Locke (1960) and Marx (1970) had visions of history in which a state of nature or society based on the land gives way to an age of money (our own) whose contradictions should lead to a just society based on fair reward for human creativity. So how are these broad classes of interest manifested in the struggle for the value generated by electronic commerce? If the owners of money and labour were first allied against the landlords (industrial capitalism) and then landlords and capitalists united to control the workers (state capitalism), how are the classes aligned in the present phase of virtual capitalism?

The landlord class has by no means rolled over and died; but the internet offers a means of escape from land shortage, indeed from spatial constraints of all kinds. The territorial controls once exercised by the landed aristocracy has largely now passed to national governments. Territorial states are able to extract taxes and rents from all money transactions taking place inside or across the boundaries of their jurisdiction. This has been greatly facilitated by the advances in bureaucracy made over the last 150 years; but it becomes more difficult when the source of value shifts from car factories and downtown shopping centres to commodity exchange conducted at the speed of light across borders. The system of involuntary transfers (taxation and rents on physical assets) could once be justified in terms of economic security for all. But that principle has been under attack by the neo-liberal consensus for over two decades now.

The capitalists have come a long way too. Having formed an alliance with the traditional rulers from the 1860s onwards, they absorbed and ultimately defeated the challenge posed by the workers. The recent revival of free market liberalism provides triumphal evidence of that victory. But the relationship of capital to the state has become increasingly moot. Money has always had an international dimension and the corporations that dominate world capitalism today are less obviously tied to their nations of origin than before. There are now some three dozen firms with an annual turnover of $\$ 30-50$ bn, larger than the GDP of all but eight countries. Moreover, half of the world's 500 largest firms are American and a third European So the world economy is controlled today by a few firms of western origin but with dubious national loyalties. Capital and the nation-state have always had a 
relationship of conflict and co-operation. The wave of anti-trust legislation that accompanied the rise of monopolists like John D. Rockefeller in the early $20^{\text {th }}$ century is matched today by the feebler efforts of governments to contain the economic power of Microsoft and a few companies like it. The idea of profit as a form of rent (income from property) has been confirmed, even if the burden has shifted from workers to consumers. The state competes for a share of the value of commodities in the form of taxes. But both rent and tax depend on a system of legal coercion, on a realistic threat of punishment, to make people pay up. This remains a shared concern of governments and corporations alike.

So where does that leave the rest of us? If Marx and Engels (1968) could identify the general interest with a growing body of factory workers tied to machines owned by capitalists, the majority of us now enter the economic process primarily as consumers. Economic agency is largely a matter of spending money. Despite the collapse of traditional industries in recent decades, there are still those who argue that workers associations, unions, remain the best hope for organized resistance to big business. State capitalism once made people believe in society as a place with one fixed point. But now the internet points to a more plural version of society composed of mobile networks. The mass of its ordinary users have a common interest, as individuals and pressure groups, in avoiding unreasonable regulation and retaining the economic benefits of their equal

Table 2. The three classes of political economy

\begin{tabular}{c|c|c|c}
\hline World & Nature & Society & Humanity \\
\hline Knowledge & Science & Religion/Science & Art \\
\hline Resources & Environment & Money & Human creativity \\
\hline Factors & Land & Capital & Labour \\
\hline Classes 1 & Landlords & Capitalists & Workers \\
\hline Income & Rent & Profit & Wages \\
\hline Classes 2 & Governments & Corporations & Persons \\
\hline Income & Tax/Rent & Profit/Rent & Exchange \\
\hline
\end{tabular}

Horizontes Antropológicos, Porto Alegre, ano 10, n. 21, p. 15-40, jan./jun. 2004 
exchanges. So we may provisionally accord to the "wired" a class identity in opposition to governments and corporations.

The main players in the political economy of the internet are thus governments, corporations and the rest of us, the people (the small minority who are wired). The landed interest, following a class alliance between landlords and capitalists forged in the mid- $19^{\text {th }}$ century, now takes the principal form of territorial power, the coercive capacity of states to extract taxes and rents on threat of punishment or by right of eminent domain. Capitalist profit is now concentrated in a handful of huge transnational corporations whose interest is to keep up the price of commodities and to guarantee income from property (rent) in the face of resistance to payment. On an analogy with the workers who tended the factory machines (themselves initially a very small minority), we could start by looking at the wired, the ordinary people who exchange services as equals on the internet, as representatives of the general human interest. Governments and corporations need each other, for sure, but their interests are far from coincident. Both may be vulnerable to self-conscious use of internet resources by democratic movements. The main threat to us all is the jealous concentration of state and corporate power to block our collective potential to build a just society with shared responsibility for life on this planet. We could do worse then than return to Ricardo's focus on how wealth is distributed in human society and, in particular, on the contradiction between coercive demands for tax and rent and the formation of a world market where people freely exchange services as equals, using money instruments of their own devising (Greco, 2001).

This rather abstract formulation can be seen at work concretely in current conflicts over intellectual property rights. The fight is on to save the commons of human culture, society and environment from the encroachments of corporate private property. This is no longer mainly a question of conserving the earth's natural resources, although it is definitely that too, nor of the deterioration of public services left to the mercies of privatized agencies. The internet has raised the significance of intangible commodities. Increasingly we buy and sell ideas; and their reproduction is made infinitely easier by digital technologies. Accordingly, the large corporations have launched a campaign to assert their exclusive ownership of what until recently might reasonably have been considered shared culture to which all had free and equal access. Across the board, separate battles 
are being fought, without any real sense of the common cause that they embody. The "napsterization" of popular music, harbinger of peer-to-peer exchange between individual computers, is one such battle pitting the feudal barons of the music business against our common right to transmit songs as we wish. The world of the moving image, of film, television and video, is likewise a site of struggle sharpened by fast-breaking technologies affecting their distribution and use. In numerous subtle and not-so-subtle ways, our ability to draw freely on a common heritage of language, literature and law is being undermined by the aggressive assertion of copyright. People who never knew they shared a common infrastructure of culture are now being forced to acknowledge it by aggressive policies of corporate privatization. And these policies are being promoted at the international level by the same American government whose armed forces now seem free to run amok in the world.

In the case of the internet, what began as a free communications network for a scientific minority is now the contested domain of giant corporations and governments. The open source software movement, setting Linux and an army of hackers against Microsoft's monopoly, has opened up fissures within corporate capitalism itself. The shift to manufacturing food varieties has introduced a similar struggle to agriculture, amplified by a revival of 'organic' farming in the context of growing public concern about genetic modification. The pharmaceutical companies try to ward off the threat posed to their lucrative monopolies by cheap generics aimed at the Third World populations who need them most. The buzzword is "intellectual property rights", slogan of a corporate capitalism determined to impose antiquated "command and control" methods on world markets whose constitutive governments have been cowed into passivity. The largest demonstrations against the neo-liberal world order, from Seattle to Genoa, have been mobilized to a significant degree by the need to oppose this particular version of global private property. The events of September $11^{\text {th }}$ have temporarily diminished this movement, especially in North America, just as they have added to the powers of coercion at the disposal of governments everywhere. In this sense, the global movement for greater democracy and less inequality has suffered a reverse.

It is a widely shared and justified belief that the age of money, whose culmination we are witnessing today, is not in the interest of most human 
beings, that the American government and giant corporations are indifferent to that common interest of humanity. The rest of the world needs Americans to join them in the struggle for decent human standards in social life. They bring tremendous resources of technology, education and economic power to that struggle, but above all they bring their country's liberal political traditions. It would be a pity if the effect of September $11^{\text {th }}$ were to obscure that possibility of global democratic solidarity, leaving the world stage to Texas oilmen and Muslim fanatics, with their mutual conspiracy to divide and rule.

\section{The real and the virtual}

The digital revolution is driven by a desire to replicate at distance or by means of computers experiences that we normally associate with face-toface human encounters. All communication, whether the exchange of words or money, has a virtual aspect in that symbols and their media of circulation stand for what people really do for each other. It usually involves the exercise of imagination, an ability to construct meanings across the gap between symbol and reality. The power of the book depended for so long on sustaining that leap of faith in the possibility of human communication. In that sense, capitalism was always virtual. Indeed Marx's intellectual effort was devoted to revealing how the power of money was mystified through its appearance as things (coins, products, machinery) rather than as relations between living men (Marx, 1970, p. 71-83). Both Marx and Weber (1981) were at pains to show how capitalists sought to detach their money-making activities, as far as possible, from real conditions obstructing their purposes. Money-lending, the practice of charging interest on loans without any intervening act of production or exchange, is one of the oldest forms of capitalism. So the idea of the money circuit becoming separated from reality is hardly new. Yet there are changes taking place which deserve a distinctive label and, for the time being, "virtual capitalism" will have to do.

The point of virtualism (Carrier; Miller, 1998) is abstraction and this in turn is a function of the shift to ever more inclusive levels of exchange, to the world market as principal point of reference for economic activity, rather than the nation-state. But reliance on more abstract forms of communication carries with it the potential for real persons to be involved with each other 
at a distance in very concrete ways. The idea of "virtual reality" expresses this double movement: on the one hand machines whose complexity their users cannot possibly understand, on the other live experiences "as good as" real. It is the same with money. Capitalism has become virtual in two main senses: the shift from material production (agriculture and manufacturing) to information services; and the corresponding detachment of the circulation of money from production and trade. This in turn is an aspect of the latest stage of the machine revolution at the millennium (Hart, 2001). What would constitute an anthropology of all this?

Daniel Miller and Don Slater (2001) have good news for traditional ethnographers: the internet does not make any difference. In The Internet: an ethnographic approach, their fieldwork-based monograph on Trinidad, they rightly argue that cyberspace should not be treated as a separate sphere of social activity; but, instead of exploring the dialectic of virtual and real experience, they reduce the former to the latter, claiming that what matters is the location of internet users in everyday life, where they can be studied by ethnographers, of course. This leads them to ignore business-to-business exchange (b2b) altogether and to approach e-commerce solely through business-customer interaction on websites. In order to generalize from a small sample of households, they assert the unity of "Trinidadians" as a national group in defiance of fifty years debate about the racial and class composition of Creole society. So the old Malinowskian recipe appears to be alive and well in the insular Caribbean. But there has to be more to it than that.

If we would make a better world, rather than just contemplate it, one prerequisite is to learn to think creatively in terms that both reflect reality and reach out for imagined possibilities. This in turn depends on capturing what is essential about the world we live in, its movement and direction, not just its stable forms. The idea of virtual reality goes to the heart of the matter. It expresses the form of movement that interests me - extension from the actual to the possible. "Virtual" means existing in the mind, but not in fact. When combined with "reality", it means a product of the imagination that is almost but not quite real. In technical terms, "virtual reality" is a computer simulation that enables the effects of operations to be shown in real time. The word "real" connotes something genuine, authentic, serious. In philosophy it means existing objectively in the world; in economics it is actual purchasing power; in law it is fixed, landed property; in optics it is an image formed by the convergence of light rays in space; and in 
mathematics, real numbers are, of course, not imaginary ones. "Reality" is present, in terms of both time and space ("seeing is believing"); and its opposite is imagined connection at distance, something as old as story-telling and books, but now given a new impetus by the internet. Already the experience of near synchrony at distance, the compression of time and space, is altering our conceptions of social relationships, of place and movement.

What interests me is less the digital divide between people with and without access to the internet, the "wired" elite versus the "unwired" masses, but how what we do offline influences what we do on it and vice versa. In this, I have taken some inspiration from Martin Heidegger's The Fundamental Concepts of Metaphysics: World, Finitude, Solitude (2001). He says there that "world" is an abstract metaphysical category for each of us (all that relates to or affects the life of a person) and its dialectical counterpart is "solitude", the idea of the isolated individual. Every human subject makes a world of his or her own whose centre is the self.. The world opens up only to the extent that we recognize ourselves as finite, as individual, and this should lead us to "finitude", the concrete specifics of time and place in which we necessarily live. So "world" is relative both to an abstract version of subjectivity and, more important, to our particularity in the world (seen as position and movement in time and space).

The internet is often represented as a self-sufficient universe with its own distinctive characteristics, as when Castells (1996) writes of the rise of a new ideal type, "network society". The idea that each of us lives alone (solitude) in a world largely of our own making seems to be more real when we go online. But both terms are imagined as well as being reciprocal; they are equally abstract and untenable as an object of inquiry. We approach them from a relative location in society where we actually live, as Miller and Slater say. Therefore it cannot be satisfactory to study the social forms of the internet independently of what people bring to it from elsewhere in their lives. This social life of people off-line is an invisible presence when they are on it. It would be wrong, however, to deny any autonomy at all to "virtual reality". Would we dream of reducing literature to the circumstances of readers? And this too is Heidegger's point. "World" and "solitude" may be artificial abstractions, but they do affect how we behave in "finitude". The dialectical triad forms an interactive set: 


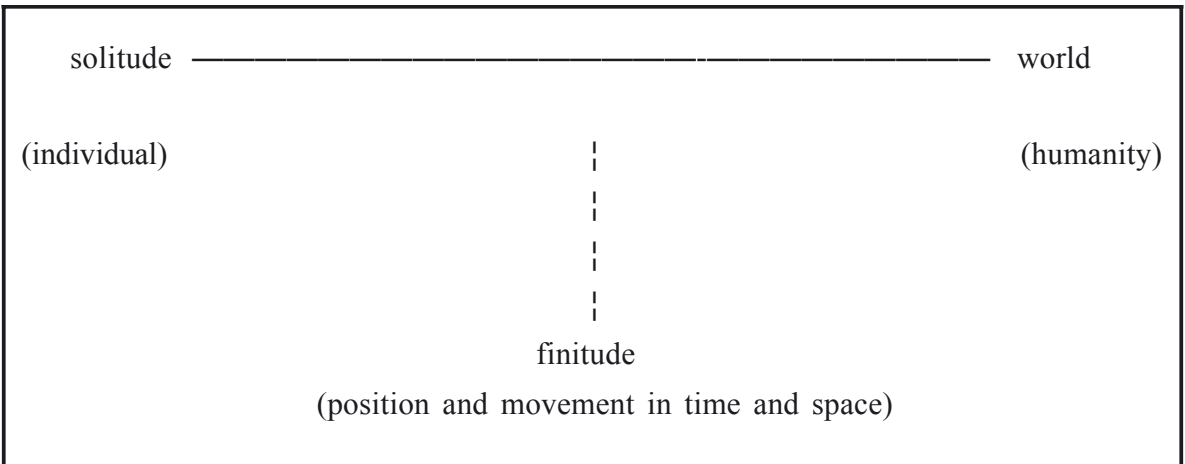

Diagram 1. Heidegger's dialectical metaphysics

\section{A Kantian anthropology for the internet age}

What then might be an anthropology for the internet age? I would start with Immanuel Kant's Perpetual Peace: a Philosophical Sketch (1795). He held that Cosmopolitan Right, the basic right of all world citizens, should rest on conditions of universal hospitality, that is, the right of a stranger not to be treated with hostility when he arrives on someone else's territory. In other words, we should be free to go wherever we like in the world, since it belongs to all of us equally. The contrast with our routine experience of international travel today could not be more marked. He says, "The peoples of the earth have entered in varying degree into a universal community, and it has developed to the point where a violation of rights in one part of the world is felt everywhere. The idea of a cosmopolitan right is not fantastic and overstrained; it is a necessary complement to the unwritten code of political and international right, transforming it into a universal right of humanity." This confident sense of an emergent world order, written over 200 years ago by the man who defined "anthropology" for modern purposes (Kant, 1977), can now be seen to be a product of the high point of the liberal revolution, before it was overwhelmed by its twin offspring, industrial capitalism and the nation state (Hart, 2003). We now live in a less confident world, but it can still generate moments that touch our universal humanity, like the first man to orbit the earth in space or a Chinese man confronting a tank on global television. 
Kant believed that human co-operation in society required us to rely on personal judgement moderated by common sense, in the double meaning of shared intelligence and taste. This common sense, also the title of his contemporary Tom Paine's (1995) revolutionary pamphlet that launched the American war of independence, was generated in everyday life, in shared social experience (good food, good talk, good company). Earlier he wrote an essay, "Idea for a universal history with a cosmopolitan purpose" (Kant, 1991), which included these propositions:

In man (as the only rational creature on earth) those natural faculties which aim at the use of reason shall be fully developed in the species, not in the individual.

The means that nature employs to accomplish the development of all faculties is the antagonism of men in society, since this antagonism becomes, in the end, the cause of a lawful order of this society.

The latest problem for mankind, the solution of which nature forces us to seek, is the achievement of a civil society which is capable of administering law universally.

This problem is both the most difficult and the last to be solved by mankind.

A philosophical attempt to write a universal world history according to a plan of nature which aims at perfect civic association of mankind must be considered to be possible and even as capable of furthering nature's purpose.

The world is much more socially integrated today than two centuries ago and its economy is palpably unjust. We have barely survived three world wars (two hot, one cold) and brutality provokes fear everywhere. Moreover, the natural (we would say "ecological") consequences of human actions are likely to be severely disruptive, if left unchecked. Histories of the universe we inhabit do seem to be indispensable to the construction of institutions capable of administering justice worldwide. When Roy Rappaport (1999, p. 461) wrote recently that "Humanity...is that part of the world through which the world as a whole can think about itself", he was repeating the central idea of Kant's prescient essay. The task of building a global civil society for the $21^{\text {st }}$ century is urgent and anthropological visions must play their part in that.

Copernicus solved the problem of the movement of the heavenly bodies by having the spectator revolve while they were at rest, instead of them revolve around the spectator. Kant extended this achievement for physics 
into metaphysics (Cassirer, 1981, p. 148-149). In his preface to The Critique of Pure Reason, he writes, "Hitherto it has been assumed that all our knowledge must conform to objects... (but what) if we suppose that objects must conform to our knowledge?". In order to understand the world, we must begin not with the empirical existence of objects, but with the reasoning embedded in our experience itself and in all the judgments we have made. Which is to say that the world is inside each of us as much as it is out there. This is why one definition of "world" is "all that relates to or affects the life of a person". Our task is to bring the two poles together as subjective individuals who share the object world in common with the rest of humanity.

The 19th and 20th centuries, in identifying society with the state, constitute a counter-revolution against Kant's Copernican revolution. This was launched by Hegel (1952), whose Philosophy of Right contains the programmes of all three founding fathers of modern social theory (Marx, Weber, Durkheim) rolled into one. This counter-revolution was only truly consummated after the first world war. The result was a separation of the personal from the impersonal, the subject from the object, humanism from science. It was enshrined in the academic division of labour and it is why most people have never heard of Kant's seminal contribution to anthropology. This is the split that the decline of state capitalism in the face of the digital revolution might allow us to reverse. In my book (Hart, 2001), I argued that the cheapening of the cost of information transfers as a result of the digital revolution makes it possible for much more information about individuals to enter into commercial transactions at distance that were until recently largely impersonal. This repersonalization of the economy has its counterpart in many aspects of contemporary social life, not just in the forms of money and exchange. It involves a new idea of the person, one that is based on digital abstractions as much as on the emergence of more concrete forms of individuality. The customized interactions that most academics now have with amazon.com and similar suppliers of books reflect this trend, at the same time personal and remote.

I do not imagine that I am alone when I respond in this way to our moment of history. Clearly one consequence of the use of new technologies in teaching is that learning can now be much more individualized and ecumenical at the same time; and this juxtaposition of self and the world in itself poses a threat to the traditions of the academic guild. Here then is one source of a renewed emphasis on subjectivity. It all adds up to a radical 
revision of conventional attitudes to subject-object relations, grounds indeed for us to reconsider the positivist dogmas on which so many modern university disciplines are based, including social anthropology's paradigm of scientific ethnography (Grimshaw; Hart, 1993, 1995). It has long been obvious to me that learning anthropology would be impossible if we were not, each of us, human beings in the first place. Anthropologists who once could rely on public ignorance as support for their exotic tales must now cope with mass mobility and communications. We have to consider seriously what our expertise can offer that is not delivered more effectively through novels and films, journalism or tourism. We live in a time when both the rhetoric and the reality of markets encourage individuals to choose the means of their own Enlightenment. It would be surprising if trends in the teaching of anthropology did not reflect all this; perhaps we are on the verge of a new paradigm for the discipline, one that will reflect the social and technological changes of which the internet is the most tangible symbol.

\section{References}

CARRIER, J.; MILLER, D. Virtualism: a new political economy. Oxford: Berg, 1998.

CASSIRER, E. Kant's Life and Thought. New Haven: Yale University Press, 1981.

CASTELlS, M. The Information Age: Economy, Society and Culture (v. 1: the rise of network society). Oxford: Blackwell, 1996.

COMTE, A. Cours de la philosophie positive. Paris: Hermann, 1975. CRABTREE, J. Richard Arkwright. New York: Macmillan, 1923.

DICKENS, C. Hard Times. London: Bradbury and Evans, 1854.

DURKHEIM, E. The Elementary Forms of the Religious Life. Glencoe, IL: Free Press, 1965.

GOODY, J. The Domestication of the Savage Mind. Cambridge: Cambridge University Press, 1977.

GOODY, J. The Interface Between the Oral and the Written. Cambridge: Cambridge University Press, 1987. 
GRECO, T. Money: understanding and making alternatives to legal tender. Burlington, VT: Chelsea Green, 2001.

GRIMSHAW, A.; HART, K. Anthropology and the Crisis of the Intellectuals. Cambridge: Prickly Pear Press, 1993.

GRIMSHAW, A.; HART, K. The rise and fall of scientific ethnography. In: AHMED, A.; SHORE, C. (Ed.). The Future of Anthropology. London: Athlone Press, 1995. p. 46-64

HART, K. Money in an Unequal World. London: Texere, 2001. (First published as The Memory Bank. London: Profile, 2000). See: <http:// www.thememorybank.co.uk>.

HART, K. Studying World Society as a Vocation. In: GOLDSMITHS Anthropology Research Papers N. 9. London: Anthropology Department, Goldsmiths College, 2003.

HEGEL, G. W. F. The Philosophy of Right. London: Oxford University Press, 1952.

HEIDEGGER, M. The Fundamental Concepts of Metaphysics: World, Finitude, Solitude. Bloomington: Indiana University Press, 2001.

KANT, I. Perpetual Peace: a philosophical sketch. 1795. In: <http:// www.mtholyoke.edu/acad/intrel/kant/kant1.htm>.

KANT, I. Anthropology form a Pragmatic Point of View. Carbondale, IL: University of Southern Illinois Press, 1977.

KANT, I. Idea for a universal history with cosmopolitan intent. In: FRIEDRICH, C. (Ed.). The Philosophy of Kant. New York: Modern Library, 1991. p. 41-53.

KEYNES, J. M. A Treatise on Money. London: Macmillan, 1930. 2 v.

LOCKE, J. Two Treatises of Government. Cambridge: Cambridge University Press, 1960.

McKITTERICK, D. A History of Cambridge University Press: Vol. 1: Printing and the book trade in Cambridge, 1534-1698. Cambridge: Cambridge University Press, 1992.

MARX, K. Capital: a critique of political economy. London: Lawrence and Wishart, 1970. v. 1.

MARX, K.; ENGELS, F. The Manifesto of the Communist Party. In: MARX-ENGELS Selected Works. London: Lawrence and Wishart, 1968. 
MILLER, D.; SLATER, D. The Internet: an ethnographic approach. Oxford: Berg, 2001.

NAUGHTON, J. A Brief History of the Future: the origins of the internet. London: Weidenfeld and Nicholson, 1999.

PAINE, T. Collected Writings: Common Sense, The Crisis etc. New York: Literary Classics of the United States, 1995.

RAPPAPORT, R. Ritual and Religion in the Making of Humanity. Cambridge: Cambridge University Press, 1999.

RICARDO, D. Principles of Political Economy and Taxation. London: Penguin, 1971.

SHELL, M. The Economy of Literature. Baltimore, MD: Johns Hopkins University Press, 1978.

UNITED NATIONS DEVELOPMENT PROGRAM. Human Development Report. New York, 1998.

US DEPARTMENT OF COMMERCE. The Emerging Digital Economy. Washington DC: 1998. See: <http://www.commerce.gov>.

WEBER, M. General Economic History. New Brunswick, NJ: Transaction Books, 1981. 